\title{
Preparation of Biological Fish Silage and its Effect on the Performance and Meat Quality Characteristics of Quails (Coturnix coturnix japonica)
}

\author{
José Carmen Ramírez Ramírez ${ }^{1 *}$, José Inés Ibarra ${ }^{1}$, Francisco Arce Romero ${ }^{1}$, Petra Rosas \\ Ulloa $^{2}$, José Armando Ulloa ${ }^{2}$, Keiko Shirai Matsumoto ${ }^{3}$, Belinda Vallejo Cordoba ${ }^{4}$ and $^{2}$ \\ Miguel Ángel Mazorra Manzano ${ }^{4}$ \\ ${ }^{1}$ Laboratorio de Bromatología y Nutrición Animal; Unidad Académica de Medicina Veterinaria y Zootecnia; \\ Universidad Autónoma de Nayarit; México. ${ }^{2}$ Centro de Tecnología de Alimentos; Universidad Autónoma de Nayarit \\ ${ }^{3}$ Laboratorio de Biopolímeros; Universidad Autónoma Metropolitana Unidad; Iztapalapa - México - D. F. \\ ${ }^{4}$ Laboratorio de Calidad; Autenticidad y Trazabilidad de Alimentos; Centro de Investigación en Alimentación y \\ Desarrollo; A.C. - Hermosillo Sonora - México
}

\begin{abstract}
The aim of the present study was to produce fish silage by lactic acid fermentation and evaluate its use in feeding of quails (Coturnix coturnix japonica). An oven-dried mixture of fish silage and soybean meal (1:1 w/w) was used to prepare the diets with different levels of inclusion $(0,10,20$ and 30\%) and evaluate its effect on the performance and meat quality of 160 quails. The inclusion level did not affect the growth and feed conversion ratio. The carcass yield $(70.3 \%)$ and sensory quality of breast meat were not significantly different among the treatments $(p>0.05)$. However, the concentration of unsaturated fatty acids such as oleic (C18:1n9C), linoleic (C18:2n6C), linolenic (C18:3n3), arachidonic (C20:4n6), cis eicosapentaenoic (C20:5n3) and cis docosahexaenoic (C22:6n3) increased in quail breast meat with the inclusion of fish silage:soybean mixture in the diet $(p<0.05)$. Fish silage and its use in quail diets could offer a good alternative for fish waste utilization as feedstuff component for the improvement of fatty acid composition in its breast meat.
\end{abstract}

Key words: fish wastes, biological silage, quails feeding, meat quality

\section{INTRODUCTION}

Fish processing for human consumption yields around $40 \%$ of edible meat, while the remnant $60 \%$ composed of bones, skin, head, viscera, meat scraps and scales, is fishery by-products (Gildberg 1993). Commonly, the fishery by-products are discarded as waste all over the world that causes serious environmental problems and economic losses (Kjos et al. 2000; Barroga et al. 2001). It is estimated that fish waste production is between 17.9 and 39.5 million tons per year, representing an important loss of valuable nutrients. Fish waste can be transformed into fish-meal. However, its production process is considered expensive. The high prices of fish-meal and its periodic scarcity have encouraged researchers to look for alternative protein feedstuffs (Fagbenro and Jauncey 1998). Fish silage has been considered an alternative process to improve the use of fish waste, or fishery by-products providing with a high quality protein source for animal feeding (Zinudheen et al. 2008). Fish silage can be produced either by the addition of acids to fish, or fish waste (chemical silage), or

*Author for correspondence: cara_ram@hotmail.com 
by adding a carbon source along with lactobacilli species for lactic acid fermentation (biological silage) (Ramirez-Ramirez et al. 2008).

During the fermentation, lactic acid bacteria (LAB) transform sugars into lactic acid with the concomitant decrease in the $\mathrm{pH}$ of the mixture (around 4.5). The low $\mathrm{pH}$ along with bacteriocin molecules produced by certain LAB prevents the growth of harmful organisms (Shirai et al. 2001). Biological fish silage production offers a great potential for the conversion of an underutilized protein to a valuable hydrolyzed product (Fagbenro and Jauncey 1998; Plascencia et al. 2002; Shirai and Ramírez-Ramírez 2011). Vidotti et al. (2002) reported that the proteins from biological silage were more digestible than those obtained by the chemical silage due to the autolytic process catalyzed by the enzymes present in the fish waste that degraded the proteins into short peptides and free amino acids. The process is accelerated by proteases and lactic acid secreted from LAB (Yin et al. 2005). Lactic fermentation provides fat stability in fish silage, improving its acceptability in the animal feed (Enes-Dapkevicius et al. 2007).

Biological fish silage is considered a valuable source of $\mathrm{LAB}$, which act as probiotics in silagefed animals bringing health benefits (Yin et al. 2005; García et al. 2007). Fish silage has adequate levels of essential amino acids (Vidotti et al. 2003; Ramírez-Ramírez 2009), which can be used as a high nutritional value protein source for the feeding of different animal species such as broilers (Espe et al. 1992; Kjos et al. 2000; SantanaDelgado et al. 2008; Al-Marzooqi et al. 2010), pigs (Kjos et al. 1999), laying hens (Kjos et al. 2001), lambs (Barroga et al. 2001), fish (Fagbenro and Jauncey 1998; Vidotti et al. 2002; Borghesi et al. 2008) and laying quails (Zinudheen et al. 2008). It has been reported that the use of diets with fish oil and fish silage may increase the content of polyunsaturated (PUFA) and long-chain omega-3 (C20:1, C22:1, C22:5 and C22:6) fatty acids in pig and broiler meat (Kjos et al. 1999, 2000). This may be beneficial for human nutrition, since the consumption of long-chain omega-3 fatty acid may strength immune and nervous systems, as well as prevention of the cardiovascular diseases and some types of cancer (Carroll 1986; Shirai and Ramírez-Ramírez 2011). To the best of our knowledge, there are no reports on the use of fish silage in quails feeding for meat production. Therefore, the objective of this study was to produce biological fish silage and evaluate its inclusion in quails feeding to assess the impact on the growth performance, carcass yield, sensory quality and fatty acid content in meat.

\section{MATERIALS AND METHODS}

\section{Fish silage production}

Fresh fish by-products mixture (MixW), which contained heads, viscera, skin, bones and meat scraps of the following species: Bagre panamensis, salema butterfish (Peprilus snyderi), Mexican barracuda (Sphyraena ensis), derbio (Trachynotus ovatus), meagre (Argyrosomus regius) and common two-banded seabream (Diplodus vulgaris) were obtained from the fishery plants located in San Blas Port, Nayarit (Mexico). Fish by-products were minced through a 5 -mm sieve using a meat mincer (TORREY 32, Mexico). Sugar cane molasses supplied by the sugar mill "El Molino S.A. de C.V.", Tepic Nayarit, was used as carbon source. Sugar cane molasses contained (\%) water 25.1, ashes 10.4 and soluble carbohydrates 55.7. Lactobacillus sp. B2 was used as starter, which was cultivated in MRS (Man Rogosa and Sharpe) broth at $30^{\circ} \mathrm{C}$ during $24 \mathrm{~h}$ until a concentration of $1 \times 10^{9} \mathrm{cfu} / \mathrm{mL}$ was reached. Sugar cane molasses were added to MixW (18.0\% wet basis) and inoculated with Lactobacillus sp. B2 (5.0\% wet basis). The fermentation was carried out at pilot scale using the methodology described by Ramirez-Ramírez (2008).

\section{Analyses of fish silage}

The $\mathrm{pH}$ of fish silage was measured using a potentiometer UB10, UltraBasic (Denver Instrument, USA). Fish silage samples were diluted in distilled water $(1: 10)$ and the lactic acid concentration $(\%)$ was determined by titration with $0.1 \mathrm{~N} \mathrm{NaOH}$ until a final $\mathrm{pH}$ of 7.5. Fermentation was carried out for four days (the fish silage reached a $\mathrm{pH}$ value of 4.4 and a lactic acid content of $4.45 \%$ ). Proximal composition of MixW and silage samples was determined using standard methods (AOAC 2000) while amino acids composition was performed according to the method reported by Vázquez-Ortiz et al. (1995). Microbial analysis of fish silage was determined by colony enumeration of mesophiles, coliforms, lactic acid bacteria, yeast and fungi (Shirai et al. 2001; Ramírez-Ramírez 2009). 
In order to estimate the proteins digestion at stomach and small intestine level, the method in vitro reported by Calsamiglia and Stern (1995) was used with slight modifications. Briefly, a fish silage sample of $15 \mathrm{mg}$ of nitrogen in $10 \mathrm{~mL}$ of a $0.1 \mathrm{~N} \mathrm{HCl}$ solution $(\mathrm{pH} 1.9)$ containing $1.0 \mathrm{~g} / \mathrm{L}$ of pepsin (Sigma P-7012, Sigma) was incubated at $38^{\circ} \mathrm{C}$. After $1 \mathrm{~h}$, the $\mathrm{pH}$ was neutralized using 0.5 $\mathrm{mL}$ of $1 \mathrm{~N} \mathrm{NaOH}$, then $13.5 \mathrm{~mL}$ of $0.5 \mathrm{M}$ phosphate buffer ( $\mathrm{pH}$ 7.8) containing pancreatin (0.3\%) (Sigma P-7545, Sigma) was added. The samples were incubated $\left(38^{\circ} \mathrm{C}\right)$ under constant shaking for $24 \mathrm{~h}$. After this, $3.0 \mathrm{~mL}$ of $6.1 \mathrm{~N}$ trichloroacetic acid solution (TCA) was added to precipitate undigested proteins and kept for 15 min. Samples were centrifuged at $10,000 \times \mathrm{g}$ at $4^{\circ} \mathrm{C}$ for $15 \mathrm{~min}$ (Beckman J2-M1Centrifuge, Beckman Coulter, USA). Total soluble nitrogen was determined by Kjeldahl method (AOAC 2000) and digestible protein in pepsin-pancreatin was calculated with the following expression:

$$
\text { digestible protein }(\%)=\frac{\text { Soluble nitrogen in TCA }}{\text { Total nitrogen of the sample }} \times 100
$$

\section{Experimental diets}

The semi-liquid fish silage obtained was mixed with soybean meal in a 1:1 ratio and the resulting mixture was oven-dried at $45^{\circ} \mathrm{C}$ for $48 \mathrm{~h}$. Dried mixture was used in the experimental diets formulation (flour form) for the growth performance of quails using inclusion levels of 0 , 10, 20 and 30\% (Table 1). Control diet (number 1) consisted predominantly of soybean meal as supplemental protein source. Protein content in all experimental diets was adjusted in order to satisfy the requirements of quails (NRC 1994). Chemical composition of experimental diets was determined using official methods (AOAC 2000).

Table 1 - Composition of experimental diets used in feeding of quails (Coturnix coturnix japonica).

\begin{tabular}{lcccc}
\hline Ingredient (g/100g) & \multicolumn{3}{c}{ Diets } \\
\hline & $\mathbf{1}$ (Control) & $\mathbf{2}$ & $\mathbf{3}$ & $\mathbf{4}$ \\
Maize & 52.5 & 52.5 & 52.5 & 52.5 \\
Fish silage- soybean meal (50:50) & 0 & 10.0 & 20.0 & 30.0 \\
Soybean meal (44\% of PC) & 40.4 & 30.4 & 20.4 & 10.4 \\
Orthophosphate & 1.5 & 1.5 & 1.5 & 1.5 \\
Soybean oil & 2.8 & 2.8 & 2.8 & 2.8 \\
Calcium (38\%) & 1.0 & 1.0 & 1.0 & 1.0 \\
Refined salt & 0.3 & 0.3 & 0.3 & 0.3 \\
Novasil plus & 0.25 & 0.25 & 0.25 & 0.25 \\
Sodium bicarbonate & 0.18 & 0.18 & 0.18 & 0.18 \\
Metionine & 0.11 & 0.11 & 0.11 & 0.11 \\
Px-v10-cod* & 1.0 & 1.0 & 1.0 & 1.0 \\
\hline
\end{tabular}

* = Pre mix of vitamins and minerals for growth performance of quails.

\section{Bird management}

The biological evaluation of the diets was performed in a commercial farm under closed housing system, using 160 quails (Coturnix coturnix japonica) unsexed for meat production, 21 days old and $78.06 \pm 3.96 \mathrm{~g}$ average weight. Four cages $(78 \mathrm{~cm}$ long, $55 \mathrm{~cm}$ wide and $35 \mathrm{~cm}$ high) were used. Each cage was divided with wire cloth into four compartments and 10 quails were randomly assigned in each compartment. Four replications per treatment (experimental diets) were carried out. Experimental diets were randomly distributed and each group of 10 quails received $700 \mathrm{~g}$ of food daily. Experiment was performed during April and May. Animals were exposed to natural lighting, $55 \%$ relative humidity and a average temperature of $28^{\circ} \mathrm{C}$. Birds remained under hygienic conditions and were provided with water ad libitum.

\section{Measurements}

The weight of the quails was registered in the morning at the beginning of the experiment before feeding and then every week for 35 days to record the weight gain. Food offered and refused was recorded daily to determinate the feed intake. Based on the feed intake and weight gain, weekly feed conversion ratio was calculated.

\section{Evaluation of carcass yield and sensory quality of meat}

After the growth performance trial, five quails from each of the experimental treatments were chosen randomly. Body weights of quails were 
recorded and slaughtered in a slaughterhouse attached to farm production to evaluate the carcass and meat quality characteristics. The slaughter was made by cervical dislocation, followed by exsanguination. Carcasses weight was recorded and the yield (\%) was calculated as part of final live body weight of quails. Then the carcasses were wrapped in plastic bags and immediately frozen $\left(-20^{\circ} \mathrm{C}\right)$. A month after the freezing, the sensory evaluation of meat was carried out. The carcasses were thawed in a microwave oven and then were cooked keeping the carcasses in closed plastic bags, and introduced into hot water $\left(80^{\circ} \mathrm{C} / 45\right.$ minutes). Breast meat of cooked quails carcasses was separated and sensory evaluation was conducted by a trained panel of 14 panelists who answered a questionnaire with a scale of 1 to 9 , where 1 was the lowest and 9 the highest intensity for color, odor, off-odor, flavor, offflavor, tenderness, juiciness and total quality.

\section{Fatty acid content in meat of quails}

Lipids were extracted from quail breast meat using chloroform/methanol $(2: 1 \mathrm{v} / \mathrm{v})$ solvent and in a 1:20 proportion according to Folch et al. (1957). Fatty acid composition was determined as described by Park and Goins (1994). Briefly, 30 mg lipids were dissolved into $0.1 \mathrm{~mL}$ methylene cloride and $1.0 \mathrm{~mL} \mathrm{NaOH} 0.5 \mathrm{~N}$ in methanol. After nitrogen flushing and screw-capping, the test tubes were heated in water bath at $90^{\circ} \mathrm{C}$ for $10 \mathrm{~min}$. After cooling at room temperature, $1.0 \mathrm{~mL}$ of $14 \%$ boron trifluoride in methanol was added and heated again $90^{\circ} \mathrm{C}$ for $10 \mathrm{~min}$ after nitrogen flushing. The tubes were removed and cooled to room temperature $\left(25^{\circ} \mathrm{C}\right)$. The fatty acid methyl esters (FAMES) were extracted with $0.5 \mathrm{~mL}$ of hexane by vigorous agitation and FAMES composition was analyzed by GC using a Hewlett Packard 6890 gas chromatograph with flame ionization detector (FID) and an analytical column Supelco 2560 (100 m X $0.25 \mathrm{~mm} \mathrm{X} 0.2 \mu \mathrm{m}$ ). The oven temperature was programmed from 100 to $190^{\circ} \mathrm{C}$ at $15^{\circ} \mathrm{C} / \mathrm{min}$ and then to $220^{\circ} \mathrm{C}$ during 45 min. The carrier gas was $\mathrm{He}$, injection mode split and inlet temperature detector at 220 and $260^{\circ} \mathrm{C}$, respectively.

\section{Statistical analysis}

Data obtained from the performance trial (feed intake, weight gain and feed conversion ratio), carcass yield, sensory quality attributes and fatty acid composition of meat were statistically analyzed by one-way ANOVA for a completely randomized design. The Tukey-Kramer test for the means comparison was used at a significance level $(\mathrm{p}=0.05)$. The analyses were conducted with the NCSS 2007 program (NCSS Inc., USA).

\section{RESULTS AND DISCUSSION}

Fish silage composition and protein digestibility Fish waste and fish silage contained 52.4 and $39.9 \%$ of protein and 24.5 and $14.5 \%$ of lipids, respectively, (Table 2). Ash content was similar in the fish waste and fish silage. However, the content of nitrogen-free extract (carbohydrates) was higher in the fish silage due to added molasses (Table 2).

Table 2 - Proximate composition (\%)*, acidity and protein digestibility in vitro of fish waste and fish silage.

\begin{tabular}{lcc}
\hline Component & Fish waste & $\begin{array}{c}\text { Fish } \\
\text { silage }\end{array}$ \\
\hline Moisture & $70.3 \pm 0.4$ & $65.5 \pm 0.3$ \\
Crude protein $(\mathrm{Nx6.25)}$ & $52.4 \pm 0.9$ & $39.9 \pm 0.7$ \\
Ether extract & $24.5 \pm 0.6$ & $14.5 \pm 0.4$ \\
Ash & $19.0 \pm 0.5$ & $18.0 \pm 0.6$ \\
Nitrogen free extract & $3.6 \pm 0.2$ & $26.9 \pm 0.6$ \\
pH & $6.49 \pm 0.03$ & $4.4 \pm 0.02$ \\
Lactic acid (\%) & $0.34 \pm 0.003$ & $4.45 \pm 0.01$ \\
Protein digestibility (\%) & $69.00 \pm 1.51$ & $81.61 \pm 0.9$ \\
\hline * Mean \pm SD values, $(\mathrm{n}=3)$, expressed in dry basis.
\end{tabular}

The decrease in $\mathrm{pH}$ and high lactic acid production prevented the growth of harmful microorganisms, which allowed the preservation of fish silage. The product showed grayish brown color, pleasant sweet aroma and faint fish odor, this latter caused by the residual molasses, or aromatic compounds released by proteolytic activity, thus improving the sensorial properties (Bulut et al. 2005). The protein hydrolysis occurring during the fermentation increased the digestibility of fish silage (69 to $81.6 \%$ ), therefore fish silage was more convenient in diets formulation. This could be due to the release of peptides and free amino acids resulting from protein hydrolysis, which could have potential chemo-attractants as well as nutritious stimulants in carnivorous and in other animal species (Lian et al. 2005). 


\section{Amino acid content}

In this study, fish silage had similar concentrations of histidine, threonine, methionine, valine and isoleucine to those of fish meal with the exception of glycine and tyrosine content (Table 3). White et al. (1999) reported a lower content of histidine, threonine, methionine, glycine, alanine and tyrosine in fermented silage of silver hake than that obtained in this study. In contrast, Don et al. (1993) reported higher amino acid content in fermented silage of salmon viscera compared to the present results, except for glycine and tyrosine. Most of the amino acids content was close to half of that reported for fermented silage from tilapia wastes (Vidotti et al. 2003). However, the same authors reported two-fold more aspartic and glutamic acids and lower tyrosine than fish silage obtained in this study.

Zinudheen et al. (2008) reported higher values in amino acid score of biological fish silage from surimi processing waste and Santana-Delgado et al. (2008) in chemical silage of whole Spanish mackerel.

Table 3 - Aminoacid content (g/100g protein) $*$ in fish silage and fish meal.

\begin{tabular}{ccc}
\hline Amino acid & Fish silage & Fish meal \\
\hline Aspartic acid & 3.1 & 5.8 \\
Glutamic acid & 4.4 & 8.7 \\
Serine & 1.7 & 2.9 \\
Histidine & 1.8 & 1.3 \\
Glycine & 7.7 & 5.2 \\
Threonine & 2.4 & 2.8 \\
Arginine & 1.9 & 5.7 \\
Alanine & 5.2 & 4.4 \\
Tirosine & 4.3 & 2.0 \\
Metionine & 2.0 & 1.7 \\
Valine & 2.5 & 2.9 \\
Phenilalanine & 1.7 & 2.5 \\
Isoleucine & 2.4 & 2.6 \\
Leucine & 3.2 & 4.5 \\
Lysine & 2.2 & 3.9
\end{tabular}

$*=$ Mean values $(\mathrm{n}=3)$.

\section{Proximate composition of experimental diets}

The proximate chemical composition of experimental diets is presented in Table 4. The average dry matter content was 89.1 and $88.7 \%$ for the control and diets with fish silage, respectively. Crude protein content was similar in all the experimental diets, which were adequate to meet the requirements of quails (Gorrachategui 1996). Lipids and minerals content were higher in the diets with fish silage, which could be due to the high content of these nutrients in the unfermented fish waste (Table 2). Crude fiber content of the experimental diets was low and met the minimum requirement for growing the quail (Gorrachategui 1996).

Table 4 - Proximate analysis* of experimental diets used in feeding trial of quails (Coturnix coturnix japonica).

\begin{tabular}{|c|c|}
\hline $\begin{array}{l}\text { Component } \\
\text { (g/100 g) }\end{array}$ & Diet \\
\hline & 1 (Control) \\
\hline Moisture & $10.9 \pm 0.611 .5 \pm 0.911 .3 \pm 0.611 .2 \pm 0.3$ \\
\hline $\begin{array}{l}\text { Crude } \\
\text { protein } \\
(\mathrm{N} 6.25)\end{array}$ & $21.1 \pm 0.220 .3 \pm 0.521 .0 \pm 0.920 .4 \pm 0.7$ \\
\hline Ether extract & $3.8 \pm 0.4 \quad 7.3 \pm 0.6 \quad 7.7 \pm 0.6 \quad 9.6 \pm 1.1$ \\
\hline Crude fiber & $3.3 \pm 0.2 \quad 2.8 \pm 0.3 \quad 2.6 \pm 0.2 \quad 2.1 \pm 0.3$ \\
\hline Ash & $9.8 \pm 0.1\lfloor 1.4 \pm 0.1 \quad 12.3 \pm 0.913 .0 \pm 0.6$ \\
\hline $\begin{array}{l}\text { Nitrogen } \\
\text { free extract }\end{array}$ & $51.1 \pm 1.0 \quad 46.8 \pm 1.145 .0 \pm 1.643 .7 \pm 1.0$ \\
\hline
\end{tabular}

\section{Growth and feed conversion ratio}

The level of fish silage in the diet did not affect the growth rate of quails ( $p>0.05)$. However, after 21 days, the inclusion of 20 and $30 \%$ of fish silage:soybean mixture in the diets improved the weight gain of quails (Fig. 1). This was very likely due to the similar amino acid content of fish silage compared to fish meal (Ramírez-Ramírez 2009).

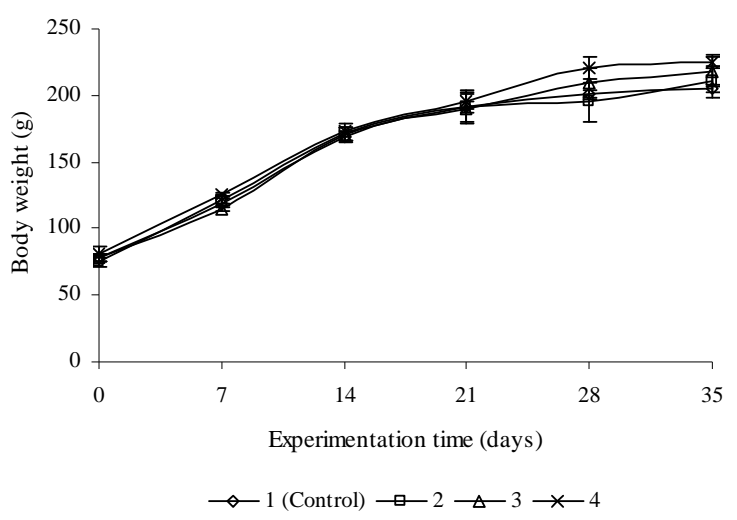

Figure 1 - Growth response of quails fed with diets containing different levels $(1=0 \%, 2=10 \%$, $3=20 \%$ and $4=30 \%$ ) of fish silage:soybean mixture.

Another reason could be the content of soluble protein in the diet, which could be rapidly absorbed, resulting an early start of protein synthesis (Espe et al. 1992). In this sense, the high 
protein digestibility of silage used might have influenced the growth of quails.

The results obtained showed a trend similar to those reported by Santana-Delgado et al. (2008), who found no significant difference on weight gain among the treatments in broilers feed with increasing amounts of fish silage $(p>0.05)$. However, it has been reported that a better growth development is obtained when part of the protein of the diet was replaced with fish silage in feed broilers (Espe et al. 1992; Al-Marzooqi et al. 2010).

In this study, the weekly feed conversion ratio was different for each of the diets during the 35 days of the experiment (Table 5). Although there was no significant difference between the treatments during each week $(p>0.05)$, feed conversion ratio was better at 14 days (Table 5). However, at day
21 and 28, feed conversion values were acceptable and consistent with the recommendations for this line of quails (Gorrachategui 1996).

These results showed a similar pattern to those reported by Espe et al. (1992), who did not find significant difference in feed intake, weight gain and feed efficiency by including fish silage up to $30 \%$ in broilers feed. The results obtained at day 7 using $10 \%$ of dried fish silage:soybean mixture were in concordance with those reported by Denli et al. (2004) who included black seed oil in the feed of quails (Coturnix coturnix japonica). Feed conversion values after 35 days of the experiment showed low efficiency of feed for all the treatments, so commercially it would not be advisable to fatten up the quails until that time (Table 5).

Table 5 - Feed conversion ratio (g feed/g gain) ${ }^{\mathrm{a}, \mathrm{b}}$ of quails fed with diets containing different levels of fish silage:soybean mixture.

\begin{tabular}{cccccc}
\hline Diet* & \multicolumn{5}{c}{ Time (days) } \\
\hline & 7 & 14 & 21 & 28 & 35 \\
1 & $3.10 \pm 0.24$ & $2.92 \pm 0.22$ & $3.67 \pm 0.31$ & $4.63 \pm 0.38$ & $5.76 \pm 0.50$ \\
2 & $2.62 \pm 0.26$ & $2.65 \pm 0.17$ & $3.38 \pm 0.37$ & $4.37 \pm 0.32$ & $5.48 \pm 0.45$ \\
3 & $3.16 \pm 0.19$ & $2.72 \pm 0.20$ & $3.62 \pm 0.41$ & $4.23 \pm 0.47$ & $5.24 \pm 0.55$ \\
4 & $2.85 \pm 0.44$ & $2.89 \pm 0.36$ & $3.55 \pm 0.31$ & $4.11 \pm 0.28$ & $4.99 \pm 0.51$ \\
\hline
\end{tabular}

${ }^{\mathrm{a}}$ Mean \pm SD values.

${ }^{\mathrm{b}} \mathrm{n}=4$; data from four replicates of 10 birds each.

$=(1=$ control $=0 \%, 2=10 \%, 3=20 \%, 4=30 \%)$ of fish silage:soybean mixture, respectively.

\section{Carcass yield and sensory quality of meat}

The level of fish silage in the feed did not affect hot carcass yield, giving an average value of the four treatments of $70.30 \pm 1.66 \%(p>0.05)$. The results agreed with those reported by Denli et al. (2004) for the same line of quails. Concerning sensory quality, quail breast meat attributes were not affected significantly by the addition of fish silage in the diet $(p>0.05)$, thus, the meat was successfully accepted by the panelists (Table 6). To the best of our knowledge, this is the first report on the use of fish silage in the diet of quails and its effect on the sensory quality of meat. Contrary to this study, it has been reported that the addition (30\%) of fish silage:corn (8:1.5 ratio) mixture in the diets fed to the birds caused an off flavour in birds breast, which was described as "fishy" by the sensory panel (Al-Marzooqy et al. 2010). Krogdahl (1985) reported that fish silage oil in feed $(1.5 \%)$ adversely affected the sensory quality of chicken meat (leg and breast) and caused rejection by the judges.

Table 6 - Effect of diets with different levels of fish silage:soybean mixture on the sensory quality of quails breast meat.

\begin{tabular}{ccccccccc}
\hline Diet* & & \multicolumn{7}{c}{ Sensory quality attribute $^{\mathbf{a}}$} \\
\hline & Color & Odor & Off-Odor & Flavor & Off-Flavor & Tenderness & Juiciness & Total quality \\
1 & 7.50 & 7.79 & 1.00 & 7.21 & 1.28 & 7.21 & 6.57 & 7.50 \\
2 & 6.93 & 8.0 & 0.93 & 7.28 & 1.07 & 7.71 & 7.00 & 7.50 \\
3 & 7.35 & 7.43 & 0.93 & 7.43 & 0.93 & 7.71 & 7.00 & 7.64 \\
4 & 6.93 & 7.07 & 0.86 & 6.78 & 1.00 & 7.93 & 7.00 & 7.5 \\
\hline
\end{tabular}

${ }^{a}$ Mean values of panelists answers $(\mathrm{n}=14)$.

$*=(1=$ control $=0 \%, 2=10 \%, 3=20 \%, 4=30 \%)$ of fish silage: soybean mixture, respectively.

Scale of 1 to 9 , where 1 was the lowest and 9 the highest intensity for each sensory quality attribute. 
Lopez-Ferrer et al. (1999) reported that the addition of fish oil in chicken food $(8.2 \%)$ produced an unacceptable taste of the meat. Kjos et al. (2000) added fish silage (5\%) and fish oil (1.7 to $2.5 \%$ ) in broiler chickens feed, which caused odor and taste of fish in the leg meat. The same authors reported lower values of odor, flavor, juiciness and tenderness intensity of chicken meat than those obtained in this study for quail meat. It has been also reported that the addition of fishmeal together with fish silage in the broiler diet (4.0\% each) produced strong fish odor and flavor in the meat (Mielnik et al. 2002). In this regard, present findings could be very valuable because the addition of dried fish silage:soybean mixture up to $30 \%$ in the feed did not alter the sensory quality of quail meat.

\section{Fatty acid composition}

The fatty acid composition of quail breast meat is shown in Table 7. Results showed that fish silage had a significant effect on concentration of fatty acids. The content of saturated fatty acid as myristic (C14), pentadecanoic (C15), palmitic (C16) and stearic (C18) was increased with increasing dried fish silage:soybean mixture from
10 to $30 \%$ ( $p<0.05$ ). The level of fish silage had no effect on the concentrations of heptadecanoic acid (C17) and unsaturated like cis-10 heptadecenoico (17:1), elaidic (C18:1n9t), vaccenic (C18:1n7), gamma-linolenic (C18:3n6), cis-11-eicosenoic (C20:1), cis-11,14-eicosadienóico (C20:2), cis8,11,14-eicosatrienoic (C20:3n6) and adrenic $(\mathrm{C} 22: 4 \mathrm{n} 6)(\mathrm{p}>0.05)$. However, the concentration of oleic (C18:1n9C), linoleic (C18:2n6C), linolenic (C18:3n3), arachidonic (C20:4n6), cis eicosapentaenoic $(\mathrm{C} 20: 5 \mathrm{n} 3)$ and cis docosahexaenoic (C22:6n3) fatty acid increased with fish silage:soybean mixture in the diet $(p<0.05)$. Similar results were reported in broilers (Lopez-Ferrer et al. 1999; Kjos et al. 2000).

The results obtained of the present study showed that the inclusion of fish silage in quails diet increased the unsaturated fatty acids in the meat. This finding appeared very important since diet intake with omega-3 PUFAs has been reported to reduce the levels of triglyceride, increase highdensity lipoprotein cholesterol, increase glucoseinduced insulin secretion and reduce the incidence of cardiovascular diseases among other beneficial effects (Rudkowska 2009; Shirai and RamírezRamírez 2011).

Table 7 - Effect of diets with different levels of fish silage:soybean mixture on the fatty acid composition of quails breast meat (g/100 g wet sample)*.

\begin{tabular}{|c|c|c|c|c|}
\hline Fatty acid & 1 (Control) & 2 & 3 & 4 \\
\hline C12:0 & $0.025 \mathrm{a}$ & $0.040 \mathrm{a}$ & $0.030 \mathrm{a}$ & $0.027 \mathrm{a}$ \\
\hline C14:0 & $0.080 \mathrm{~b}$ & $0.080 \mathrm{~b}$ & $0.115 \mathrm{a}$ & $0.135 \mathrm{a}$ \\
\hline C14:1 & $0.027 \mathrm{a}$ & $0.017 \mathrm{a}$ & $0.032 \mathrm{a}$ & $0.030 \mathrm{a}$ \\
\hline C15:0 & $0.053 \mathrm{c}$ & $0.062 \mathrm{c}$ & $0.082 \mathrm{~b}$ & $0.110 \mathrm{a}$ \\
\hline C16:0 & $2.211 \mathrm{c}$ & $2.122 \mathrm{c}$ & $3.040 \mathrm{a}$ & $2.625 \mathrm{~b}$ \\
\hline C16:1 & $0.860 \mathrm{a}$ & $0.695 \mathrm{c}$ & $0.817 \mathrm{~b}$ & $0.587 \mathrm{~d}$ \\
\hline C17:0 & $0.033 \mathrm{a}$ & $0.030 \mathrm{a}$ & $0.042 \mathrm{a}$ & $0.052 \mathrm{a}$ \\
\hline C17:1 & $0.058 \mathrm{a}$ & $0.052 \mathrm{a}$ & $0.052 \mathrm{a}$ & $0.055 \mathrm{a}$ \\
\hline C18:0 & $0.960 \mathrm{c}$ & $0.812 \mathrm{~d}$ & $1.120 \mathrm{~b}$ & $1.452 \mathrm{a}$ \\
\hline C18:1n9 & $0.058 \mathrm{a}$ & $0.037 \mathrm{a}$ & $0.065 \mathrm{a}$ & $0.050 \mathrm{a}$ \\
\hline C18:1n9 & $4.88 \mathrm{~b}$ & $4.957 \mathrm{~b}$ & $5.032 \mathrm{a}$ & $4.370 \mathrm{c}$ \\
\hline C18:1n7 & $0.028 \mathrm{a}$ & $0.022 \mathrm{a}$ & $0.027 \mathrm{a}$ & $0.025 \mathrm{a}$ \\
\hline C18:2n6 & $2.831 \mathrm{~d}$ & $3.397 \mathrm{a}$ & $2.912 \mathrm{c}$ & $3.215 \mathrm{~b}$ \\
\hline C18:3n6 & $0.013 \mathrm{a}$ & $0.015 \mathrm{a}$ & $0.015 \mathrm{a}$ & $0.012 \mathrm{a}$ \\
\hline C20:1 & $0.039 \mathrm{a}$ & $0.042 \mathrm{a}$ & $0.037 \mathrm{a}$ & $0.055 \mathrm{a}$ \\
\hline $\mathrm{C} 18: 3 \mathrm{n} 3$ & $0.184 \mathrm{c}$ & $0.240 \mathrm{a}$ & $0.200 \mathrm{~b}$ & $0.172 \mathrm{~d}$ \\
\hline C20:2 & $0.024 \mathrm{a}$ & $0.017 \mathrm{a}$ & $0.022 \mathrm{a}$ & $0.025 \mathrm{a}$ \\
\hline C20:3n6 & $0.021 \mathrm{a}$ & $0.020 \mathrm{a}$ & $0.020 \mathrm{a}$ & $0.022 \mathrm{a}$ \\
\hline C20:4n6 & $0.472 \mathrm{c}$ & $0.475 \mathrm{c}$ & $0.550 \mathrm{~b}$ & $0.610 \mathrm{a}$ \\
\hline $\mathrm{C} 20: 5 \mathrm{n} 3$ & $0.021 \mathrm{c}$ & $0.020 \mathrm{c}$ & $0.037 \mathrm{~b}$ & $0.045 \mathrm{a}$ \\
\hline $\mathrm{C} 22: 4 \mathrm{n} 6$ & $0.016 \mathrm{a}$ & $0.020 \mathrm{a}$ & $0.020 \mathrm{a}$ & $0.020 \mathrm{a}$ \\
\hline C22:6n3 & $0.175 \mathrm{~d}$ & $0.187 \mathrm{c}$ & $0.250 \mathrm{~b}$ & $0.322 \mathrm{a}$ \\
\hline
\end{tabular}

* = Mean values $(\mathrm{n}=3)$.

a-d: Different letters in a row indicate significant differences among treatments $(\mathrm{p}<0.05)$. 


\section{CONCLUSION}

Fish silage obtained by the use of LAB fermentation represents an alternative process for the use of fish waste. The inclusion of fish silage in quail diets neither adversely affected the productive parameters, nor the sensory quality of the meat, nor carcass yield. The content of polyunsaturated fatty acid in quail's meat could be increased with the inclusion of fish silage in the diet. The biological fish silage production is an attractive biotechnological process to utilize fish waste and reduce environmental problems.

\section{ACKNOWLEDGMENTS}

The authors thank "Codornices y Derivados del Pacífico, S.A. de C.V., Granja Alejandra" for providing facilities to carry out this work. The technical assistance of Maria del Carmen Estrada Montoya from CIAD is greatly appreciated.

\section{REFERENCES}

Al-Marzooqi W, Al-Farsi MA, Kadim IT, Mahgoub O, Goddard JS. The effect of feeding different levels of sardine fish silage on broiler performance, meat quality and sensory characteristics under closed and open-sided housing systems. Asian-Aust J Anim Sci. 2010; 23(12): 1614-1625.

AOAC, Official Methods of Analysis $17^{\text {th }}$ ed. Washington DC: Association of Official Analytical Chemists; 2000.

Barroga AJ, Pradhan R, Tobioka H. Evaluation of fish silage-sweet potato mixed diet with Italian ryegrass silage as basal ration on nitrogen utilization and energy balance in growing lambs. J Anim Sci. 2001; 72(3): 189-197.

Borghesi R, Portz L, Oetterer M, Zyrino JEP. Apparent digestibility coefficient of protein and aminoacids of acid, biological and enzymatic silage for Nile tilapia (Oreochromis Niloticus). Aquac Nut. 2008; 14: 242248.

Bulut C, Gunes H, Okuklu B, Harsa S, Kilic S, Coban $\mathrm{HS}$, et al. Homofermentative lactic acid bacteria of a traditional cheese, comlek peyniri from Cappadocia region. J Dairy Res. 2005; 72: 19-24.

Calsamiglia S, Stern MD. A three-step in vitro procedure for estimating intestinal digestion of protein in ruminant. J Anim Sci. 1995; 73: 1459-1465.

Carroll KK. Biological effects of fish oils in relation to chronic diseases. Lip. 1986; 21: 731-732.
Denli M, Okan F, Uluocak AN. Effect of dietary supplementation of herb essential oils on the growth performance, carcass and intestinal characteristics of quail (Coturnix coturnix japonica). South Afr J Anim Sci. 2004; 34(3): 174-179.

Enes-Dapkevicius MLN, Nout MJR, Rombouts FM, Houben JH. Preservation of blue-jack mackerel (Trachurus picturatus bowdich) silage by chemical and fermentative acidification. J Food Proc Preser. 2007; 31(4): 454-468.

Espe M, Haaland H, Njaa LR. Substitution of fish silage protein and a free amino acid mixture for fish meal protein in a chicken diet. J Sci Food Agric. 1992; 58: 315-319.

Fagbenro OA, Jauncey K. Physical and nutritional properties of moist fermented fish silage pellets as a protein supplement for tilapia (Oreochromis niloticus). Anim Feed Sci Tech. 1998; 71: 11-18.

Folch J, Lees M, Sloane Stanley GH. A simple method for the isolation and purification of total lipids from animal tissues. J Biol Chem. 1957; 226: 497-509.

García Y, Boucourt R, Acosta A, Albelo N, Núñez O. Effect of a probiotic mixture of Lactobacillus acidophilus and Lactobacillus rhamnosus on some health and physiological indicators in broilers in the tropics. Cub J Agric Sci. 2007; 41(1): 69-72.

Gildberg A. Review: Enzimic processing of marine raw materials. Proc Biochem. 1993; 28: 1-15.

Gorrachategui M. Bird feeding alternatives: Quails, pheasants and partridges. In: XII Specialization course. Advances in nutrition and animal feed. Madrid, Spain: Spanish foundation for the development of the animal nutrition; 1996. p. 161198.

Kjos NP, Skrede A, Øverland M. Effects of dietary fish silage and fish fat on growth performance and sensory quality of growing-finishing pigs. Can $J$ Anim Sci. 1999; 79: 139-147.

Kjos NP, Herstad O, Overlad M, Skrede A. Effects of dietary fish silage and fish fat on growth performance and meat quality of broiler chicks. Can J Anim Sci. 2000; 80(4): 625-632.

Kjos NP, Herstad O, Skrede A, Øverlad M. Effects of dietary fish silage and fish fat on performance and egg quality of laying hens. Can J Anim Sci. 2001; 80(4): 245-261.

Krogdahl $\AA$. Fish viscera silage as a protein source for poultry. 2. Experiments with meat-type chickens and ducks. Ac Agric. Scand. 1985; 35: 24-32.

Lian PZ, Lee CM, Park E. Characterization of squidprocessing byproduct hydrolysate and its potential as aquaculture feed ingredient. J Agric Food Chem. 2005; 53: 5587-5592.

Lopez-Ferrer S, Baucells MD, Barroeta AC, Grashorn MA. n-3 enrichment of chicken meat using fish oil: Alternative substitution with rapeseed and linseed oils. Poult Sci. 1999; 78: 356-365. 
Matsumoto Y, Saucedo-Castañeda G, Revah S, Shirai $\mathrm{K}$. Production of $\mathrm{N}$ acetylhexosaminidase of Lecanicillium lecanii by solid state and submerged fermentations utilizing shrimp waste silage as substrate and inducer. Proc Biochem. 2004; 39(6): 665-671.

Mielnik M, Herstad O, Lea P, Nordal J, Nilsson A. Sensory quality of marinated frozen stored chicken thighs as affected by dietary fish fat and vitamin E. Int J Food Sci Tech. 2002; 37: 29-39.

National Research Council. Nutrient requirements of poultry. Washington, DC: National Academy Press; 1994.

Park P, Goins R. In situ preparation of fatty acid methyl esters for analysis of fatty acid composition in foods. J Food Sci. 1994; 59: 1262-1266.

Plascencia JM, Olvera MA, Arredondo JL, Shirai K. Feasibility of fishmeal replacement by shrimp head silage protein hydrolysates in Nile Tilapia (Oreochromis niloticus L) diets. J Sci Food Agric. 2002; 82: 753-759.

Ramírez-Ramírez JC, Huerta S, Arias L, Prado A, Shirai K. Utilization of shrimp by-catch and fish wastes by lactic acid fermentation and evaluation of degree of protein hydrolysis and in vitro digestibility. Rev Mex Ing Quim. 2008; 7(3): 195-204.

Ramírez-Ramírez JC. Utilization of shrimp bycatch and fishery byproducts through fish silage production. PhD. Thesis. Mexico City, Mexico: Universidad Autónoma Metropolitana; 2009.

Rudkowska I. Functional foods for health: Focus on diabetes. Matur. 2009; 63(3): 263-269.

Santana-Delgado H, Avila E, Sotelo A. Preparation of fish silage of Spanish mackerel (Scomberomorus maculates) and its evaluation in broiler diets. Anim Feed Sci Tech. 2008; 141: 129-140.

Shirai K, Guerrero I, Huerta S, Saucedo G, Castillo A, González RO, et al. Effect of initial glucose concentration and inoculation level of lactic acid bacteria in shrimp waste ensilation. Enz Microb Tech. 2001; 28: 446-452.
Shirai K, Ramírez-Ramírez JC. Utilization of fish processing by-products for bioactive compounds. In: Hall GM, editor. Fish processing, sustainability and new opportunities. Preston UK: Wiley-Blackwell; 2011. p. 236-265.

Vázquez-Ortiz FA, Caire G, Higuera-Ciapara I, Hernández G. High performance liquid chromatographic determination of free amino acids in shrimp. J Liq Chromat. 1995; 18(19): 2059-2068.

Vidotti RM, Carneiro DJ, Viegas EM. Acid and fermented silage characterization and determination of apparent digestibility coefficient of crude protein for Piaractus mesopotamicus. J World Acuac Soc. 2002; 33(1): 57-62.

Vidotti RM, Macedo EM, Carneiro DJ. Amino acid composition of processed fish silage using different raw materials. Anim Feed Sci Tech. 2003; 105: 199204.

White MB, Anderson DM, Rouvinen KI. Apparent digestibility coefficients of raw ground, acid and fermented silver hake (Merluccius bilinearis) feedstuffs for mink and evaluation of the storage stability of the silages. Can J Anim Sci. 1999; 79(3): 375-381.

Yin LJ, Tong YL, Jiang ST. Improvement of the functionality of minced mackerel by hydrolysis and subsequent lactic acid bacterial fermentation. $J$ Food Sci. 2005; 70: 172-178.

Zinudheen AA, Anandan R, Ramachandran G. Effect of dietary supplementation of fermented fish silage on egg production in Japanese quail (Coturnix coromandelica). Afr J Agric Res. 2008; 3(5): 379383.

Received: July 07, 2012; Accepted: September 12, 2013. 